\title{
Internationalization and Performance of Chinese Family Firms: The Moderating Role of Corporate Governance
}

\author{
Jane Wenzhen Lu, ${ }^{1}$ Xueji Liang, ${ }^{2}$ Mengmeng Shan, ${ }^{3}$ and \\ Xiaoya Liang ${ }^{4}$ \\ ${ }^{1}$ University of Melbourne, Australia, ${ }^{2}$ Sun Yat-sen University, China, ${ }^{3}$ Shanghai University, China, \\ and ${ }^{4}$ Fudan University, China
}

ABSTRACT This study investigates the differential effects of internationalization on two dimensions of family firms' performance: growth and profitability. Drawing on the contingency theory, we argue that the successful implementation of internationalization strategy requires an appropriate organization structure, which is usually absent in Chinese family firms. To the extent that such a structure is established, these firms can realize greater benefits from internationalization. From a sample of 225 family firms in China, our predictions receive empirical support. We find that internationalization has a positive impact on growth but a negative impact on profitability. The negative internationalization-firm profitability relationship highlights the challenges internationalizing Chinese family firms face. The positive moderating effect of corporate governance, a critical component of organization structure, underscores the need for appropriate corporate governance to support the implementation of strategy. The findings have important practical implications for the internationalization of Chinese family firms.

KEYWORDS China, corporate governance, family business, internationalization, performance

\section{INTRODUGTION}

Firms are increasingly diversifying the geographic scope of their business activities. The effectiveness of this strategy has been investigated extensively by researchers in strategic management and international business with a focus on large and well-established firms from developed economies (McDougall \& Oviatt, 1996). Recent research has shown that geographic expansion comes with a set of benefits and costs that determine the performance effects from internationalization (Lu \& Beamish, 2004) and that such benefits and costs vary by firm type (Lu \& Beamish, 2001) and institutional environment (Wan \& Hoskisson, 2003). A significant development during recent years within the internationalization trend has been the increasingly active role of family firms (Zahra, 2003), especially 
family firms from emerging economies such as China, in international markets (La Porta, López de Silanes, \& Shleifer, 1999). Prior studies have examined the antecedents and processes of family firm internationalization (e.g., Claver, Rienda, \& Quer, 2009; Davis \& Harveston, 1999; Fernández \& Nieto, 2005; Gallo \& Sveen, 1991; Zahra, 2003). Yet few studies have assessed the performance effects of these internationalizing family firms, a research gap that has important implications for the further development of the family business and international business literature streams.

With regard to the family business literature, managers are more concerned about the outcomes than the antecedents of a strategy. This attention to outcomes is stronger in family firms whose managers are often the owners themselves who will bear the financial implications of the strategy. An investigation of the performance implications of family firms' internationalization strategy is much needed in the field, and doing so should help advance the internationalization of family firms and provide guidance to practitioners. Furthermore, research on family businesses has theorized their advantages and disadvantages (Erdener \& Shapiro, 2005; Fernández \& Nieto, 2005). An examination of the performance effects of the internationalization of family firms can help reveal and further refine such advantages and disadvantages.

With regard to the international business literature, the recent debate on the relationship between internationalization and performance has led to the development of a new conceptual framework (Contractor, Kundu, \& Hsu, 2003; Lu \& Beamish, 2001, 2004), but the boundary conditions of the new framework have yet to be specified. These recent developments in the internationalization-performance literature are primarily based on public firms from developed economies, probably because of the ready availability of information on these firms. In contrast with these firms, family firms have distinctive features such as the presence of owner-managers with aligned interests and their deeper involvement in operations (Jensen, 1994; Sharma, Chrisman, \& Chua, 1997). Moreover, family firms from different countries have additional features as a result of their specific institutional environments. For example, contemporary Chinese family firms have a relatively short history, as private ownership was not legally allowed in China until 1994 (Naughton, 2007). Consequently, there is a disproportionately large number of small firms in the population of Chinese family firms, and they are still evolving in formalizing their organization structure.

The distinctive features of family firms from emerging economies could well have an impact on the outcome of their internationalization, a notion we examine in this study. Such an investigation contributes to the internationalizationperformance literature, not only by enriching its empirical contexts but also by teasing out how the benefits and costs associated with internationalization may vary as firm type and institutional environment change. This contribution is theoretically important, because it highlights key boundary conditions of the internationalization-performance conceptual framework. 
We considered various plausible moderators, such as firm resources and capabilities, but most are generic to all types of firms. Family business literature emphasizes corporate governance as one important factor distinguishing public firms from family firms, especially those from emerging markets, because family firms in emerging markets are still in the evolving stage compared with public firms and family firms in developed economies (Peng, Zhang, \& Li, 2007). Given the focus of prior studies on public firms from developed economies versus our focus on family firms from emerging economies and their noticeable difference in corporate governance, we expect corporate governance to play a moderating role in the context of our study; if it does so, we will have identified a new moderator in the internationalization-performance literature, helping reconcile the mixed findings.

Finally, most of the studies on firm performance have focused on firm profitability. Because firm performance is a multidimensional construct, any individual strategy can have differential effects on different dimensions of firm performance (Delios \& Beamish, 2001). Firm growth is an important dimension of firm performance, which prior studies have largely ignored, likely because of their focus on publicly listed firms, most of which are large and may even face the pressure of downsizing. However, growth is a key organization objective for firms that are in early stages of development, such as family firms from emerging economies. Therefore, it is important to understand the effects of internationalization on both the growth and profitability of these firms. If, for example, we find that internationalization has both positive and negative effects, depending on the specific dimension of firm performance, this will indicate different motivations and goals associated with internationalization strategy and the resultant differential effects on different dimensions of performance. The findings from this study can impart new insights to the internationalization-performance literature and to other literature examining firm performance by highlighting the multidimensionality of the performance construct.

In this study, we directly test the internationalization-performance relationship in a sample of 225 family firms from China, a major emerging economy. We analyze the features of Chinese family firms and apply extant theories of internationalization to this context. Furthermore, drawing on contingency theory, we discuss the need for the adoption of appropriate corporate governance to support the implementation of internationalization by Chinese family firms and describe how it moderates the internationalization-performance relationship.

\section{THEORETICAL BACKGROUND AND HYPOTHESES}

\section{Internationalization and Performance}

Internationalization and firm performance is a popular topic in international business literature. Researchers have focused on the relationship between internationalization and firm profitability and found various effects. For example, 
studies have reported positive (e.g., Delios \& Beamish, 2001), negative (e.g., Denis, Denis, \& Yost, 2002; Geringer, Tallman, \& Olsen, 2000), and curvilinear (e.g., Contractor et al., 2003; Hitt, Hoskisson, \& Kim, 1997; Lu \& Beamish, 2001, 2004) effects or no effect at all (e.g., Brewer, 1981; Morck \& Yeung, 1991). These conflicting results suggest the complexity of the relationship between internationalization and firm performance.

In general, prior studies reporting a positive internationalization-performance relationship have theorized three broad benefits of internationalization. First, research has proposed that internationalization enables a firm to exploit its ownership advantage, such as brand equity, trademarks, or patents, by expanding to markets in which local firms do not have such advantage (e.g., Bartlett \& Ghoshal, 1989; Casson, 1982; Porter, 1986). Second, by expanding into foreign markets, firms can gain economies of scale (e.g., Buckley \& Casson, 1976; Caves, 1980; Hymer, 1960) by achieving larger volume of sales and production in multiple markets or economies of scope by adding technically related or market-related products (Teece, 1980) in different countries. Third, internationalizing firms can gain learning benefits (Buckley \& Casson, 1976), as selling in several markets leads to cumulative knowledge of the local customers' needs. The firms will also get valuable opportunities to learn from foreign firms who have cutting-edge technologies and modern management styles (Lu \& Beamish, 2001, 2004).

Studies reporting a negative or curvilinear relationship between internationalization and firm performance have highlighted the costs of internationalization. Internationalizing firms face liabilities of foreignness (Hymer, 1960; Zaheer, 1995) and newness (Stinchcombe, 1965). They confront many challenges related to operations in dissimilar markets. Firms can face difficulties in running their business in a foreign country when they are not familiar with the local suppliers, have little knowledge of the local customers' needs, and are not well connected with the local business networks. Such a situation puts internationalizing firms in a disadvantageous position, compared with their indigenous competitors, and makes it difficult for them to conduct operations as effectively as local firms. Furthermore, a new subsidiary faces the same set of challenges as a start-up that needs to establish everything from scratch. Finally, when firms reach a high level of internationalization, coordination costs tend to escalate because the crossborder communication between headquarters and subsidiaries abroad becomes less effective and managers face challenges related to information overload ( $\mathrm{Lu} \&$ Beamish, 2004).

We contend that these theorized benefits and costs may vary by organization forms and by institutional environments. For example, Hitt et al. (1997) found an inverted U-shaped relationship in a sample of large US multinational corporations in which the coordination costs were likely to outweigh the benefits at a high level of internationalization. In contrast, Lu and Beamish (2001) found a Ushaped relationship in a sample of small and medium-sized internationalizing Japanese firms suffering from liabilities of foreignness and newness. Therefore, it is 
meaningful to consider the specific benefits and costs influencing this relationship in particular contexts and to identify the boundary conditions of this relationship.

Furthermore, prior studies have focused almost exclusively on the profitability dimension of performance, either by accounting-based measures, such as return on assets, or by market-based measures, such as Tobin's q. We contend that a strategy can serve different motives and thus have differential effects on different dimensions of performance, a notion that is applicable to the internationalization strategy. Achieving firm growth can be another important goal attributed to international expansion (McDougall \& Oviatt, 1996; Oviatt \& McDougall, 2005), in addition to improving a firm's profitability, increasing organizational learning, and following customers/competitors (for a review, see Dunning, 1993). The antecedents of improved firm growth might differ from those that help improve a firm's financial performance. An examination of the effect of internationalization on the growth and profitability dimensions of performance provides a more complete picture of the internationalization-performance relationship and may help reconcile the varying results. In the following, we discuss the benefits and costs of internationalization in the context of Chinese family firms and the moderating role of corporate governance on the relationship between internationalization and the two dimensions of performance.

\section{Internationalization and Performance in Chinese Family Firms}

Family businesses are the most popular form of business organization in the world (Leach, 2007; Melin \& Nordqvist, 2007), and they play a major role in leading economic growth worldwide (Zahra, 2003), especially in Asian countries (Chang, 2003). Increasingly, more family businesses are expanding overseas; however, research on the internationalization and performance relationship of family firms is scarce.

The presence of owner-managers (Sharma et al., 1997) whose interests are aligned with those of the company (Jensen, 1994) distinguishes family firms from other types of organizations. Owner-managers' deep involvement in operations is another distinctive feature of family firms (James, 1999). Not only do Chinese family firms have these general differences from other types of firms (Casillas \& Acedo, 2005; Erdener \& Shapiro, 2005; Gallo \& Sveen, 1991; Okoroafo, 1999), but their unique features are rooted in the institutional environment as well. Given the relative short history of private ownership in contemporary China, Chinese family firms tend to be small and have limited resources. Firm capability and skills are developed to adapt to the Chinese business culture, in which information sourcing and business solutions center on guanxi, or the development and use of connections to secure favors in personal relationships (Luo, 1997) or to cultivate business transactions (Luo, 2006). The strong family-oriented values and prevalence of nepotism make the appointment of nonfamily members to top positions less common in Chinese family firms than family firms in developed economies. Finally, Chinese family 
firms face additional challenges given the fragmentation of the Chinese market and the nascent nature of its market economy. Thus, it is valuable to understand how these features affect the internationalization-performance relationship in China.

We begin by examining whether the key theoretical arguments on the benefits and costs of internationalization can be applied to the context of Chinese family firms. The literature provides little explicit discussion on the relationship between internationalization and firm growth; however, the contribution of internationalization to firm growth is straightforward. It can be inferred from the above-mentioned economies of scale, which are based on the assumption that firms can achieve a higher sales volume through entering international markets. By selling directly or indirectly to new geographic markets, a firm reaches new customers and increases its sales volume, which in turn demands higher production volume and expansion in production capacities to meet market demands. By broadening geographic markets and creating room for expansion, internationalization constitutes an essential path for firm growth.

Achieving growth by expanding into international markets might be more important to family firms from emerging economies. Many emerging economies, such as China, have fragmented domestic markets. With the existence of interstate/provincial market segmentation in China's markets (Poncet, 2003; Young, 2000), it is difficult for Chinese family firms to go beyond their original geographic location to expand domestically given the high cost of entering other markets protected by local governments. This disadvantage significantly restrains the growth of Chinese family firms. International expansion presents one solution to this problem. By expanding internationally, Chinese family firms can escape from the institutional barriers in their home country and achieve growth by operating in new geographic markets (Luo \& Tung, 2007). Therefore, internationalization is an important avenue for the growth of Chinese family firms.

Hypothesis 1: The internationalization of Chinese family firms will be positively related to their growth.

The implication of internationalization on firm profitability is a more complicated issue. Regarding the three major benefits we discussed previously, the effect of scale and scope economies is generally context free, and thus Chinese family firms can achieve these benefits from the larger volume of sales and production made possible by revenue growth in the geographic extension of markets (Kogut, 1985). The learning benefits can be of particular importance to Chinese family firms, because they are generally located in a laggard position in most industries and can benefit much from learning from the leading players in the world. However, such learning and catching up can take time. While learning can translate into long-term profitability, firms are likely to suffer from short-term losses because of the mistakes they make in the learning process. In terms of the ability to gain higher profitability from core competences, Chinese family firms are weak. As latecomers to international markets, these firms are unlikely to gain any advantages 
in competing with more established firms from developed markets; as such, they not only have fewer core competences to profit from but also are likely to suffer from disadvantages due to this lack of competences.

In addition, substantial costs arise from internationalization. Firms incur different costs as they move through stages of internationalization (Lu \& Beamish, 2004). At the initial stage when the level of internationalization is low, they face liabilities of foreignness (Hymer, 1960; Zaheer, 1995) and newness (Stinchcombe, 1965) and thus are likely to make mistakes, resulting in heightened costs. In the later stages with higher levels of internationalization, costs associated with the coordination of complex operations across diverse locations escalate. Again, because Chinese family firms are relatively early in the internationalization stage, the costs associated with liabilities of foreignness and newness should be of more relevant concern to them.

In addition, Chinese family firms may face two areas of difficulty when venturing into international markets. First, the relatively small size of Chinese family firms means that they will likely face the liability of smallness and suffer from resource constraints when expanding into international markets. These resource constraints are reflected in the shortage of both tangible resources, such as financial resources, and intangible resources, such as managerial capabilities. Johanson and Vahlne (1977) indicate that an international activity involves a decision to commit current resources to a foreign operation, including organizational, personnel, and other resources (Liu, Xiao, \& Huang, 2008) and capabilities related to building global marketing channels, obtaining information on global demands, advertising, and engaging in potential research and development. The types of capabilities required are usually quite different from those that already exist within the firm (Zahra \& Garvis, 2000), and family businesses often lack such capabilities to manage business abroad, in comparison with other types of enterprises such as public firms (Gallo \& Pont, 1996; Kets de Vries, 1993). Family firms have difficulties in accessing the requisite resources and capabilities to obtain competitive advantages in foreign markets (Fernández \& Nieto, 2005). With such resource constraints, these firms have problems in overcoming the challenges stemming from liabilities of foreignness and newness.

Second, Chinese family firms face the unique challenge of low home country legitimacy, which is also referred to as 'liability of origin' (Bartlett \& Ghoshal, 2000; Ramachandran \& Pant, 2010). Given the attributes of their home country institutions (Holburn \& Zelner, 2010), emerging market firms face disadvantages in international markets because of where they reside. Chinese products are often perceived of as low quality and thus must be sold at low prices to secure market share (Schott, 2004). Direct investments by Chinese firms are frequently discriminated against, scrutinized, or even barred by many host country governments (Ramachandran \& Pant, 2010). As Chinese family firms are subject to this liability of origin, when they expand abroad they may have difficulties in commanding high prices for their products, and their foreign subsidiaries may face different levels of suspicion by or even resistance from host country politicians, 
interest groups, environmentalists, and other relevant stakeholders. Therefore, the internationalization of Chinese family firms comes with high costs stemming not only from liabilities of foreignness and newness but also from liabilities of smallness and origin. Given the daunting challenges associated with these four liabilities, we hypothesize the following:

Hypothesis 2: The internationalization of Chinese family firms will be negatively related to their profitability.

\section{Moderating Roles of Board of Directors and Top Management Team}

Building on contingency theory (Lawrence \& Lorsch, 1967; Perrow, 1967), which emphasizes the need for an appropriate structure to support strategy, we discuss the moderating role of Chinese family firms' structure in the internationalizationperformance link. Firms employ structures to maximize the value of the strategies they implement (Caves, 1980). Although internationalization has direct performance implications, we expect these effects to vary with different firm structures. In our examination of firm structures to help determine this variance, we focus on the board of directors and top management team (TMT), two important dimensions of a firm's governance structure.

Board of directors. The board of directors plays monitoring, service, and legitimacy roles (Johnson, Daily, \& Ellstrand, 1996). In family firms, the owner-managers' aligned interest reduces the agency issue; therefore, the board of directors plays less of a monitoring role as it does in public firms (Chen \& Nowland, 2010). Boards of directors provide service by advising top managers on administrative and other managerial issues and on the formation and implementation of strategies (Johnson et al., 1996). Boards of directors can provide legitimacy by demonstrating firms' compliance to external demands for a formal structure (Pfeffer, 1972).

Both service and legitimacy roles provided by boards can help Chinese family firms reap benefits from internationalization. Boards can provide these firms with information sources (Zahra \& Pearce, 1989) and substantial institutional or business networks. Such resources are particularly valuable for small-scale Chinese family firms expanding internationally. Boards can also help them gain external legitimacy during internationalization. Having a board signals firms' resources and strategy commitment, thus increasing their chances of securing loans from financial institutions to address financial constraints, which is among the major hindrances family firms face in weak institutional environments. To foreign stakeholders, the presence of a board reduces the liability of origin. Chinese family firms' business models are built to function in weak institutional environments. As such, these firms are perceived as lacking in appropriate governance structure, especially in the eyes of foreign audiences. Establishing a board is one step toward having strong corporate governance. Thus, having a formal structure characterizes Chinese family firms 
as similar to firms in developed economies, or at least shows that they have the structure to afford international strategy. Therefore, we anticipate that boards of directors positively moderate the internationalization-performance relationship in Chinese family firms.

The extent to which Chinese family firms can benefit from having boards of directors, however, depends on the functionality of the board. The frequency of board meetings, a direct indication of board activeness, has proved to have a positive effect on operating performance (Vafeas, 1999); that is, the frequency of board meetings indicates the time dedicated to strategy formulation and quality of information available to directors (Corbetta \& Salvato, 2004). Another source of variation in board functionality is board independence, or the extent to which the board is independent of management (Fama \& Jensen, 1983); independence is usually achieved by the appointment of directors from outside the company to the board. Independent directors are typically CEOs/founders of another company, former local officers, or experts in specific areas. As the degree of board activeness and independence increases, the benefits from the service and legitimacy roles provided by the board increase, which in turn helps Chinese family firms in the process of internationalization. Therefore, we hypothesize the following:

Hypothesis 3a: Board activeness will positively moderate the relationship between internationalization and firm performance.

Hypothesis 3b: Board independence will positively moderate the relationship between internationalization and firm performance.

Family dominance in the TMT. In addition to boards of directors, family firms' TMT members can serve similar service and legitimacy roles. A TMT's ability to secure resources is greatly related to its diversity (Cannella, Park, \& Lee, 2008; Hambrick, Cho, \& Chen, 1996). Among the dimensions of TMT diversity, we contend that diversity in family membership is relevant to the degree to which Chinese family firms can benefit from internationalization.

For family firms, hiring nonfamily members for their professional talent is a major approach to professionalization (Aronoff \& Ward, 2000). Nonfamily members in TMTs are most likely professional managers, because, unlike family members who can be placed in the TMT for succession reasons, nonfamily members are hired for their talent and performance track record. As such, professional managers in the TMT can help fulfill the service and legitimacy roles. For the service role, the hiring of professional managers can help solve the problem of a lack of talent in the family, which is one of the major constraints in the expansion of family firms (Chua, Chrisman, \& Bergiel, 2009). Because of the expanded responsibilities of top managers in the process of expansion, nonfamily professional managers are more likely to have adequate and matching expertise to meet the demands of the jobs than are family members (Dyer, 1989). For the legitimacy role, nonfamily managers in the TMT can enhance the legitimacy of the firm in the eyes of external stakeholders, 
as the education background and industry and management experience of these managers signal the professionalism of the management (Aronoff \& Ward, 2000).

The benefits stemming from both the service and legitimacy roles played by nonfamily professional managers in TMTs can benefit Chinese family firms in their process of internationalization. As family firms expand into international markets, employing nonfamily managers in TMTs is essential because of the limited number of competent and willing family members. This is especially the case for Chinese family firms, given the unique Chinese culture and its weak institutional environment in which informal business relationships often play pivotal roles in determining business success (Peng, 2004). Family members who establish and run their business on a domestic scale are less likely to be competent for TMT positions with new responsibilities for international markets, because their business knowledge is either difficult to transfer to another country with a different culture or is not applicable to countries with strong institutional environments. Therefore, as Chinese family firms expand into new markets, employing nonfamily managers in the TMT is essential.

In addition to the service role, having nonfamily members in TMT positions signals to the external stakeholders the professionalism of the management. The level of professionalism of the management is an important criterion when external stakeholders evaluate the prospect of the firms and make decisions such as providing financial resources and establishing business relationships. For Chinese family firms that suffer from liabilities of smallness and origin, it is important for them to enhance the level of management professionalism in the eyes of the stakeholders to increase chances of getting scarce resources to support their internationalization activities. Taken together, we hypothesize the following:

Hypothesis 3c: The dominance of family members in the TMT will negatively moderate the relationship between internationalization and firm performance.

Figure 1 illustrates the theoretical framework of the study.

\section{METHOD}

\section{Sample and Data}

To test the hypotheses, we used data from a large-scale survey of Chinese private firms in 2008 across eight major cities in the Pearl River Delta and the Yangtze River Delta regions of China (Liang, Lu, \& Wang, 2012). A list of 4,430 private firms was drawn primarily from the 2007 Statistics Yearbook of Private Enterprises, using criteria such as industry, scale, and geographic distributions to ensure representativeness of the sample. After cases with undeliverable addresses and unreachable telephone or fax numbers were excluded, the list consisted of 1,150 private firms.

The initial contact by mail and follow-up telephone calls generated 254 valid responses. Subsequent personal visits by a team of graduate assistants to remind 


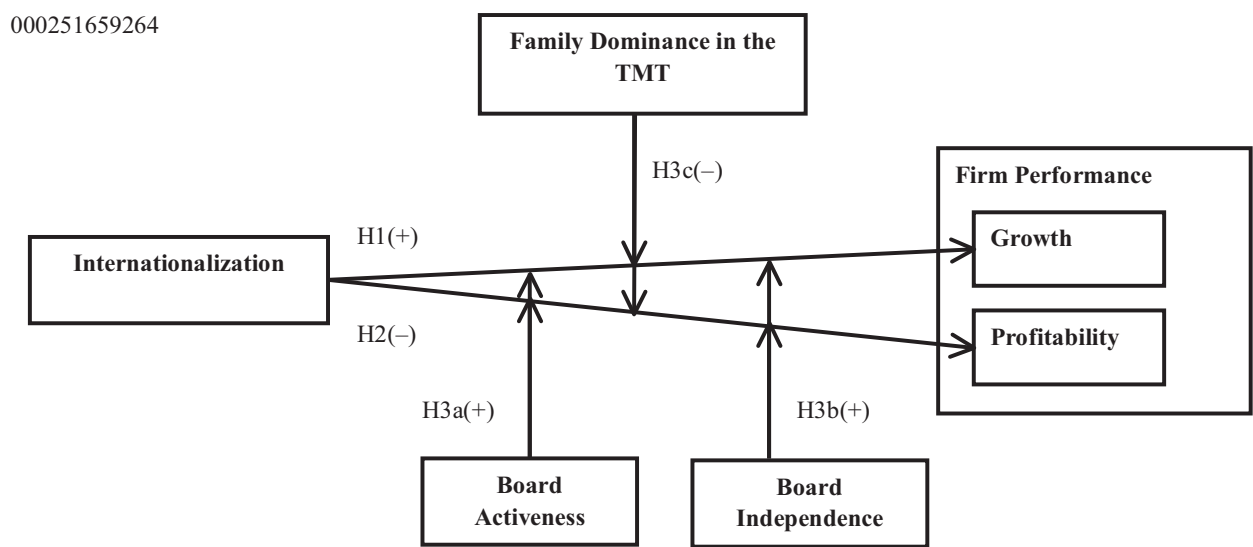

Figure 1. Theoretical framework: Outward internationalization on firm performance

and urge the completion of the questionnaires yielded another 816 responses. After responses with missing data on key firm characteristics were excluded, the sample comprised 902 firms.

Our focus is on family firms in this study, so we needed to identify those firms in the sample. Of the various ways to define family firms reported in the literature (Chua, Chrisman, \& Sharma, 1999), we used two criteria, one subjective and one objective, to define family firms for our study. In the survey instrument, we asked respondents to indicate whether they regarded their firms as family firms. Of the 902 firms, 292 identified themselves as such. We verified this subjective criterion with family ownership of the firms, an objective criterion. All 292 firms had family ownership exceeding $50 \%$. On average, the owners of the firms held $83.30 \%$ of company shares.

We then used listwise deletion, a conservative method to deal with missing data. The final sample consisted of 225 family firms. We conducted t-tests on firm characteristics such as firm size, firm age, and leverage between the final sample of 225 and the full sample of 292 family firms but did not find any significant differences.

\section{Measures}

Dependent variables. Our first dependent variable is firm growth, which is a continuous measure with information derived from the answer to the question 'What is the average growth rate of the total sales for the past three years'? The second dependent variable is profitability, measured by return on investment (ROI), a 5point scale item. This variable is based on self-rated firm performance relative to that of the main domestic competitors in the same industry. Although financial ratio generates more objective information, managers' perceptions of performance allow us to obtain a more meaningful evaluation than financial ratios from the 
firm's perspective (Sciascia \& Mazzola, 2008). The correlation coefficient between the two performance measures is 0.31 .

Independent variables. We measured firm internationalization in two ways. First, we used a binary variable to indicate whether a firm had any outward internationalization. If a firm was engaged in any outward internationalization activities, such as exporting, selling products through agents, licensing, creating joint ventures, building a wholly owned subsidiary, or international acquisition, we counted it as an internationalizing firm. In total, 113 of the 225 firms were internationalizing firms. Second, we examined the specific activities of outward internationalization and decomposed it into asset-based and contract-based internationalization. According to the internationalization stage model (Johanson \& Vahlne, 1977), contract-based entry modes (e.g., exporting, licensing) and assetbased entry modes (e.g., joint ventures, acquisitions, and wholly owned subsidiaries) are two broad categories. With direct asset investments in foreign markets, the latter represents a more serious financial commitment and therefore is deemed a more advanced stage in internationalization than the former. We categorized specific activities of outward internationalization of the firms in our sample in line with the definition of asset-based and contract-based internationalization in the literature. Of the 113 internationalizing firms, 33 had asset-based foreign direct investment (FDI).

Moderating variables. We used three variables to measure a firm's corporate governance. Board activeness refers to the intensity of board activity; we measured it with an ordinal variable indicating the frequency of board meetings each year. The values ranged from 0 to 4 , where 0 represents no board meetings or board of directors, 1 represents one board meeting, 2 indicates two to three board meetings, 3 indicates four to five board meetings, and 4 indicates six or more board meetings annually. For the measure of board independence, we used the number of independent directors. In the survey, firms filled in the number of independent directors on the board if they indicated the presence of a board of directors to the previous question. The number of independent directors on the board ranged from one to eight in our sample. The third corporate governance variable is family dominance in the TMT. We contend that the degree to which family members take top management positions indicates family dominance in the decision-making process. The survey measured this with a 5-point scale item, with intervals from none to more than $80 \%$ of TMT positions taken by family members. We operationalized family dominance in the TMT by assigning a value of 1 if a firm had more than $80 \%$ of TMT positions taken by family members and 0 if otherwise. Approximately $17 \%$ of firms had family dominance in the TMT.

Control variables. To examine the effect of internationalization on firm performance, we took into consideration factors that are known to influence this relationship. 
At the firm level, we controlled for firm size, firm age, firm stage, firm inward FDI, leverage, and guanxi. At the individual level, we included founder education, founder tenure, and founder past overseas experience. We also included industry dummy variables to account for industrial-specific factors that may affect firm performance.

Firm size is measured by the number of employees in 2007. Firm age is a logarithm function of the number of years since a firm's foundation to the year 2008. The mean firm age in our sample was about eight years, and $61 \%$ of the firms had fewer than 100 employees. So, the majority of our sample were young and small and mediumsized family firms. The third firm-level factor is firm stage, which was an ordinal variable of four values, with 1 representing the start-up stage, 2 representing the developing stage, 3 representing the mature stage, and 4 representing the saturated stage. We recoded this as a binary variable, assigning a value of 1 to the developing or mature stage and 0 to the start-up or saturated stage. Firms in the developing and mature stages should have better performance than those in the start-up and saturated stages. In total, 156 firms were in the developing or mature stage. Inward $F D I$ is another firm-level control variable; it indicates whether a firm had any experience in conducting business with foreign firms in China. Activities of inward internationalization include distributing or selling products, original equipment manufacturing, original design manufacturing, licensing, and purchasing overseas raw materials. Approximately $70 \%$ of the firms in the sample had inward FDI experiences. We also included leverage as a control variable; it takes a value of 1 if the firm secured a bank loan in the past three years and 0 if otherwise. Finally, we included guanxi, a variable that measures external ties to critical resource providers. Guanxi is an average of two items: (1) 'Compared to peer foreign firms, where does the firm stand in terms of having guanxi or social resources'? (2) 'Compared to peer stateowned firms, where does the firm stand in terms of having guanxi or social resources'? The values were from a 5 -point scale, where 1 indicated the worst and 5 indicated the best.

Family business literature provides abundant evidence for the effects of founder characteristics on the operations of family firms, particularly young family firms (Davis \& Harveston, 1999). Therefore, we included three important founder characteristics: founder education, founder tenure, and founder past overseas experience. Founder education was measured with the highest degree earned by the founder, which was an ordinal variable, where the lowest level was high school degree and the highest level was doctoral degree. Founder tenure refers to the number of years the founder had worked in a management position. About half the founders had a bachelor's degree or above, and the average founder tenure was 11.8 years. Founder past overseas experience measures whether the founder had any overseas study or work experience. Finally, we included industry dummies to control for industrial-level effects. The firms spanned a variety of sectors, including manufacturing, service, finance, commercial, public facilities, conglomerates, and others. Of the 225 firms, 48.4\% were in the manufacturing industry. 


\section{Analysis}

We used both presurvey procedures and postsurvey tests to minimize the possible threat of common method bias. The items used in this study came from a large comprehensive survey of Chinese private business, which had 241 questions. Consistent with Chang, van Witteloostuijn, and Eden's (2010) suggestions, we designed the survey with various styles of questions and Likert scales. The variables used in this study appeared in different sections of the survey, from the beginning to the end. As such, the survey respondents were not likely to anticipate the relationships we attempted to examine. In addition, 13 of the 16 items we used to develop our measures asked about factual information, which is less subject to common method bias.

Furthermore, we conducted a factor analysis on the dependent, independent, and moderating variables. The results show that the largest factor explains only approximately $30 \%$ of the total variation. We also conducted Harman's single-factor test (Podsakoff, MacKenzie, Lee, \& Podsakoff, 2003) to check for common method variance. We entered items of internationalization, growth, profitability, and the moderators into the single-factor test. The analysis allowed these variables to load on one factor to examine the fit of the confirmatory factor analysis model. The model demonstrated poor fit $\left(\chi^{2}(15)=118.99\right.$, comparative fit index $[\mathrm{CFI}]=0.83$, incremental fit index $[\mathrm{IFI}]=0.83$, and root-mean-square error of approximation [RMSEA] = 0.16). As $\mathrm{Hu}$ and Bentler (1999) recommend, the cutoff points for good model fit are 0.06 for RMSEA and 0.90 for both CFI and IFI. Thus, the tests suggest that common method variance is not responsible for the relationships among the variables.

We then applied different empirical strategies to analyze models with different dependent variables. We used ordinary-least-squares (OLS) regressions on growth, which is a continuous variable, and ordered logistic regression on ROI, which is measured by a 5-point scale.

\section{RESULTS}

Table 1 presents the descriptive statistics and pairwise correlation matrix of the variables used in this study. The correlation matrix reveals that there is no highly correlated variable, except those for the same constructs. In addition, the mean variation inflation factor for the regression model is 2.31, suggesting that multicollinearity is not a serious issue in our study (Kutner, Nachtsheim, \& Neter, 2004).

The regression results appear in Table 2, with internationalization as the independent variable, and in Table 3, with asset-based and contract-based internationalization as the independent variables. All models are significant and have reasonable explanatory power. Models 1-5 report the regression results on sales growth, and Models 6-10 report the regression results on the dependent variable $(\mathrm{ROI})$ in each table. 
Table 1. Descriptive statistics and correlation matrix

\begin{tabular}{|c|c|c|c|c|c|c|c|c|c|c|c|c|c|c|c|c|c|c|c|}
\hline & & Mean & S.D. & 1 & 2 & 3 & 4 & 5 & 6 & 7 & 8 & 9 & 10 & 11 & 12 & 13 & 14 & 15 & 16 \\
\hline 1 & Sales growth & 23.76 & 20.16 & & & & & & & & & & & & & & & & \\
\hline 2 & ROI & 3.22 & 0.99 & 0.31 & & & & & & & & & & & & & & & \\
\hline 3 & Internationalization & 0.50 & 0.50 & 0.10 & -0.11 & & & & & & & & & & & & & & \\
\hline 4 & $\begin{array}{l}\text { Asset-based } \\
\text { internationalization }\end{array}$ & 0.15 & 0.35 & 0.07 & -0.02 & 0.41 & & & & & & & & & & & & & \\
\hline 5 & $\begin{array}{l}\text { Contract-based } \\
\text { internationalization }\end{array}$ & 0.35 & 0.48 & 0.05 & -0.11 & 0.74 & -0.31 & & & & & & & & & & & & \\
\hline 6 & Firm size & 1.48 & 0.72 & 0.01 & 0.12 & 0.37 & 0.25 & 0.21 & & & & & & & & & & & \\
\hline 7 & Firm age & 1.98 & 0.67 & -0.17 & 0.01 & 0.19 & -0.03 & 0.22 & 0.38 & & & & & & & & & & \\
\hline 8 & Firm stage & 0.69 & 0.46 & 0.17 & 0.18 & 0.01 & 0.00 & 0.01 & 0.10 & 0.11 & & & & & & & & & \\
\hline 9 & Inward FDI & 0.69 & 0.46 & 0.06 & 0.07 & 0.07 & 0.03 & 0.05 & 0.06 & 0.09 & 0.12 & & & & & & & & \\
\hline 10 & Leverage & 0.47 & 0.50 & 0.15 & 0.04 & 0.12 & 0.09 & 0.06 & 0.19 & 0.12 & 0.20 & 0.14 & & & & & & & \\
\hline 11 & Guanxi & 3.18 & 0.95 & 0.09 & 0.16 & 0.04 & 0.06 & 0.00 & -0.01 & 0.13 & 0.23 & 0.05 & 0.20 & & & & & & \\
\hline 12 & Founder education & 3.24 & 1.33 & 0.15 & 0.18 & -0.06 & 0.17 & -0.19 & -0.04 & -0.22 & -0.04 & -0.05 & -0.09 & -0.03 & & & & & \\
\hline 13 & Founder tenure & 11.80 & 7.10 & -0.10 & 0.12 & 0.19 & 0.04 & 0.17 & 0.28 & 0.50 & 0.12 & 0.14 & 0.07 & -0.14 & 0.14 & & & & \\
\hline & $\begin{array}{l}\text { Founder overseas } \\
\text { experience }\end{array}$ & 0.03 & 0.11 & 0.14 & 0.01 & 0.04 & 0.06 & -0.01 & -0.08 & -0.08 & -0.01 & 0.08 & 0.05 & 0.04 & 0.06 & -0.04 & & & \\
\hline 15 & Board meeting & 0.96 & 0.36 & 0.07 & 0.11 & -0.08 & -0.01 & -0.08 & 0.07 & 0.01 & 0.11 & 0.02 & 0.14 & 0.03 & -0.03 & 0.12 & $2-0.03$ & & \\
\hline 16 & Independent director & 0.66 & 1.36 & 0.15 & 0.18 & 0.00 & 0.13 & -0.10 & 0.05 & 0.00 & 0.20 & 0.10 & 0.16 & 0.09 & -0.01 & 0.07 & $7 \quad 0.06$ & $\quad 0.51$ & \\
\hline 17 & $\begin{array}{l}\text { Family dominance in } \\
\text { the TMT }\end{array}$ & 0.17 & 0.38 & 0.02 & -0.03 & 0.16 & -0.12 & 0.26 & 0.08 & 0.04 & 0.04 & 0.02 & -0.07 & -0.07 & 0.11 & 0.06 & $5-0.05$ & -0.09 & -0.17 \\
\hline
\end{tabular}

Notes: Correlations $\geq|0.12|$ are significant at $p \leq .05 ; \mathcal{N}=225$. 
Table 2. Regression analyses: effect of outward internationalization on firm performance

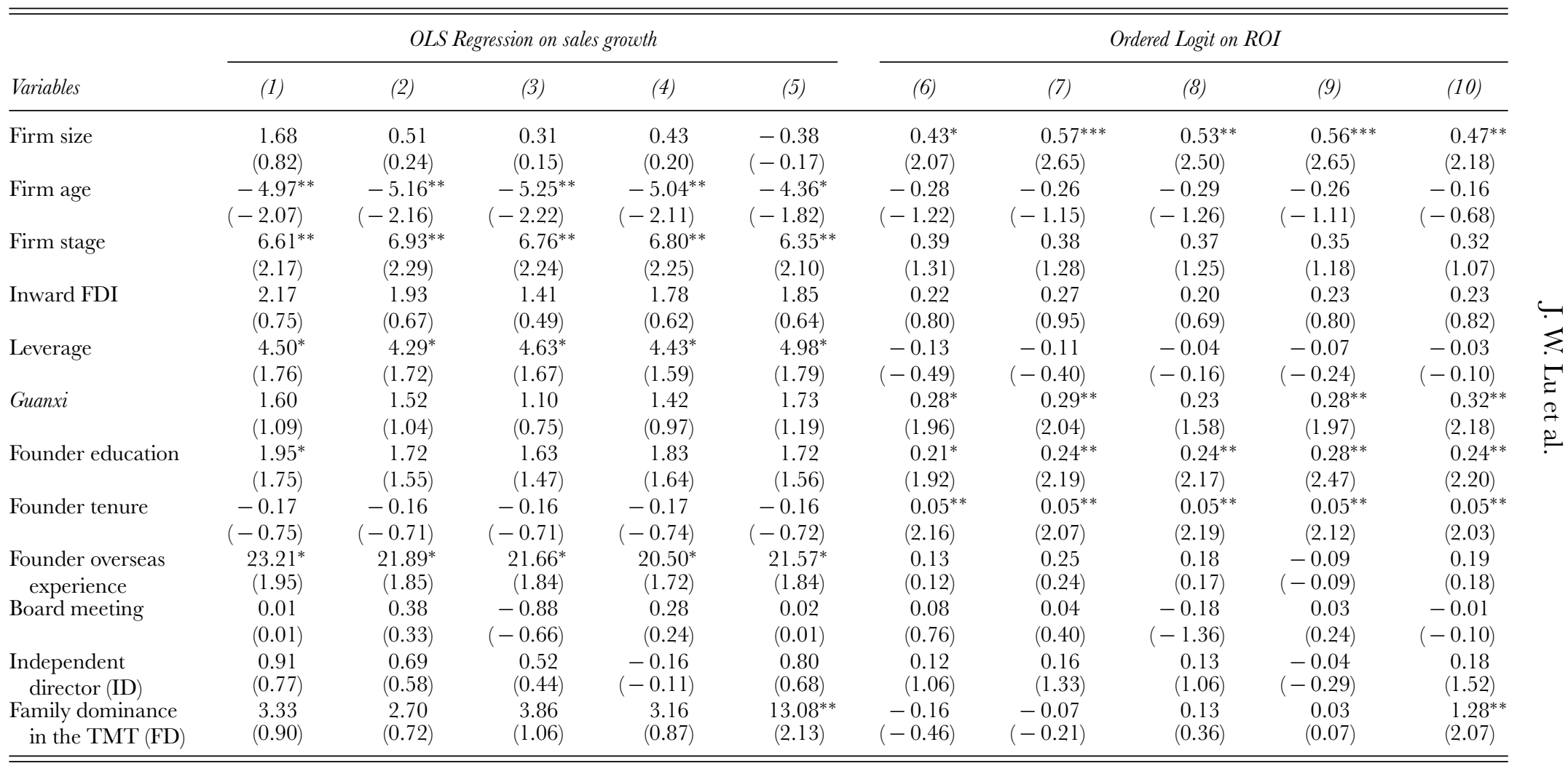


Table 2. Continued

\begin{tabular}{|c|c|c|c|c|c|c|c|c|c|c|}
\hline \multirow[b]{2}{*}{ Variables } & \multicolumn{5}{|c|}{ OLS Regression on sales growth } & \multicolumn{5}{|c|}{ Ordered Logit on ROI } \\
\hline & (1) & (2) & (3) & (4) & (5) & (6) & (7) & (8) & (9) & (10) \\
\hline Industry dummy & Included & Included & Included & Included & Included & Included & Included & Included & Included & Included \\
\hline Internationalization & & $5.69^{*}$ & 2.23 & 4.14 & $7.95^{* *}$ & & $-0.67^{* *}$ & $-1.26^{* * *}$ & $-1.00^{* * *}$ & -0.39 \\
\hline & & (1.87) & $(0.62)$ & $(1.23)$ & $(2.48)$ & & $(-2.20)$ & $(-3.47)$ & $(-2.96)$ & $(-1.20)$ \\
\hline $\begin{array}{l}\text { Intln } \times \text { Board } \\
\text { meeting }\end{array}$ & & & $\begin{array}{c}3.61^{*} \\
(1.77)\end{array}$ & & & & & $\begin{array}{l}0.62^{* * *} \\
(3.04)\end{array}$ & & \\
\hline Intln $\times$ ID & & & & $\begin{array}{l}2.10 \\
(1.06)\end{array}$ & & & & & $\begin{array}{l}0.46^{* *} \\
(2.20)\end{array}$ & \\
\hline Intln $\times$ FD & & & & & $\begin{array}{l}-15.97^{* *} \\
(-2.08)\end{array}$ & & & & & $\begin{array}{l}-2.01^{* * *} \\
(-2.62)\end{array}$ \\
\hline Log likelihood & & & & & & -289.75 & -287.30 & -282.62 & -284.77 & -283.80 \\
\hline Cragg-Uhler $R^{2}$ & & & & & & 0.16 & 0.18 & 0.22 & 0.20 & 0.21 \\
\hline$R^{2}$ & 0.16 & 0.17 & 0.18 & 0.18 & 0.19 & & & & & \\
\hline
\end{tabular}


Table 3. Regression analyses: effect of asset-based and contract-based outward internationalization on firm performance

\begin{tabular}{|c|c|c|c|c|c|c|c|c|c|c|}
\hline \multirow[b]{2}{*}{ Variables } & \multicolumn{5}{|c|}{ OLS Regression on sales growth } & \multicolumn{5}{|c|}{ Ordered Logit on ROI } \\
\hline & (1) & (2) & (3) & (4) & (5) & (6) & (7) & (8) & (9) & (10) \\
\hline \multirow[t]{2}{*}{ Firm size } & 1.68 & 0.80 & 0.58 & 0.73 & -0.05 & $0.43^{*}$ & $0.59^{* * *}$ & $0.55^{* * *}$ & $0.59^{* * *}$ & $0.51^{* *}$ \\
\hline & $(0.82)$ & $(0.37)$ & $(0.27)$ & $(0.34)$ & $(-0.02)$ & $(2.07)$ & $(2.74)$ & $(2.54)$ & $(2.77)$ & $(2.36)$ \\
\hline \multirow[t]{2}{*}{ Firm age } & $-4.97^{* *}$ & $-5.45^{* *}$ & $-5.60^{* *}$ & $-5.41^{* *}$ & $-4.46^{*}$ & -0.28 & -0.29 & -0.31 & -0.31 & -0.14 \\
\hline & $(-2.07)$ & $(-2.26)$ & $(-2.33)$ & $(-2.24)$ & $(-1.84)$ & $(-1.22)$ & $(-1.25)$ & $(-1.31)$ & $(-1.31)$ & $(-0.60)$ \\
\hline \multirow[t]{2}{*}{ Firm stage } & $6.61^{* *}$ & $6.87^{* *}$ & $6.60^{* *}$ & $6.75^{* *}$ & $5.93^{*}$ & 0.39 & 0.37 & 0.36 & 0.34 & 0.21 \\
\hline & $(2.17)$ & $(2.27)$ & $(2.19)$ & $(2.22)$ & $(1.95)$ & $(1.31)$ & $(1.23)$ & $(1.22)$ & $(1.12)$ & $(0.70)$ \\
\hline \multirow[t]{2}{*}{ Inward FDI } & 2.17 & 1.92 & 1.33 & 1.74 & 1.92 & 0.22 & 0.27 & 0.20 & 0.23 & 0.28 \\
\hline & $(0.75)$ & $(0.66)$ & $(0.46)$ & $(0.60)$ & $(0.67)$ & $(0.80)$ & $(0.96)$ & $(0.72)$ & $(0.83)$ & $(0.98)$ \\
\hline \multirow[t]{2}{*}{ Leverage } & $4.50^{*}$ & 4.32 & $4.73^{*}$ & 4.48 & $5.31^{*}$ & -0.13 & -0.10 & -0.05 & -0.06 & 0.04 \\
\hline & $(1.76)$ & $(1.55)$ & $(1.70)$ & $(1.60)$ & $(1.89)$ & $(-0.49)$ & $(-0.39)$ & $(-0.17)$ & $(-0.21)$ & $(0.15)$ \\
\hline \multirow[t]{2}{*}{ Guanxi } & 1.60 & 1.64 & 1.11 & 1.58 & 1.97 & $0.28^{*}$ & $0.30^{* *}$ & 0.24 & $0.31^{* *}$ & $0.36^{* *}$ \\
\hline & (1.09) & $(1.11)$ & $(0.75)$ & $(1.07)$ & $(1.35)$ & $(1.96)$ & $(2.11)$ & $(1.64)$ & $(2.13)$ & $(2.46)$ \\
\hline \multirow[t]{2}{*}{ Founder education } & $1.95^{*}$ & 1.79 & 1.65 & $1.94^{*}$ & 1.77 & $0.21^{*}$ & $0.25^{* *}$ & $0.25^{* *}$ & $0.29^{* *}$ & $0.24^{* *}$ \\
\hline & $(1.75)$ & $(1.61)$ & (1.48) & (1.73) & $(1.60)$ & $(1.92)$ & $(2.22)$ & $(2.19)$ & $(2.55)$ & $(2.10)$ \\
\hline \multirow[t]{2}{*}{ Founder tenure } & -0.17 & -0.15 & -0.14 & -0.15 & -0.16 & $0.05^{* *}$ & $0.05^{* *}$ & $0.05^{* *}$ & $0.05^{* *}$ & $0.04^{*}$ \\
\hline & $(-0.75)$ & $(-0.67)$ & $(-0.64)$ & $(-0.68)$ & $(-0.73)$ & $(2.16)$ & $(2.13)$ & $(2.20)$ & $(2.20)$ & $(1.95)$ \\
\hline \multirow[t]{2}{*}{ Founder overseas experience } & $23.21^{*}$ & $22.25^{*}$ & $20.44^{*}$ & $21.28^{*}$ & $22.18^{*}$ & 0.13 & 0.28 & 0.24 & 0.04 & 0.27 \\
\hline & $(1.95)$ & $(1.88)$ & $(1.72)$ & $(1.77)$ & $(1.89)$ & $(0.12)$ & $(0.27)$ & $(0.23)$ & $(0.04)$ & $(0.26)$ \\
\hline \multirow[t]{2}{*}{ Board meeting } & 0.01 & 0.34 & -0.80 & 0.19 & -0.08 & 0.08 & 0.04 & -0.19 & 0.01 & -0.03 \\
\hline & $(0.01)$ & $(0.29)$ & $(-0.59)$ & $(0.16)$ & $(-0.07)$ & $(0.76)$ & $(0.36)$ & $(-1.37)$ & $(0.13)$ & $(-0.25)$ \\
\hline \multirow[t]{2}{*}{ Independent director (ID) } & 0.91 & 0.79 & 0.39 & -0.14 & 0.97 & 0.12 & 0.17 & 0.14 & -0.04 & $0.21^{*}$ \\
\hline & $(0.77)$ & $(0.66)$ & $(0.33)$ & $(-0.09)$ & $(0.82)$ & $(1.06)$ & $(1.40)$ & $(1.14)$ & $(-0.28)$ & $(1.80)$ \\
\hline \multirow[t]{2}{*}{ Family dominance in the TMT (FD) } & 3.33 & 2.18 & 3.02 & 2.78 & $13.19^{* *}$ & -0.16 & -0.12 & 0.10 & -0.00 & $1.36^{* *}$ \\
\hline & $(0.90)$ & $(0.60)$ & $(0.81)$ & $(0.75)$ & $(2.14)$ & $(-0.46)$ & $(-0.34)$ & $(0.27)$ & $(-0.01)$ & $(2.18)$ \\
\hline Industry dummy & Included & Included & Included & Included & Included & Included & Included & Included & Included & Included \\
\hline \multirow[t]{2}{*}{ Asset-based Internationalization } & & 3.31 & -2.14 & 1.64 & 4.27 & & $-0.87^{* *}$ & $-1.33^{* * *}$ & $-1.23^{* *}$ & $-0.88^{* *}$ \\
\hline & & $(0.78)$ & $(-0.43)$ & $(0.34)$ & $(0.98)$ & & $(-2.11)$ & $(-2.69)$ & $(-2.64)$ & $(-2.02)$ \\
\hline
\end{tabular}


Table 3. Continued

\begin{tabular}{|c|c|c|c|c|c|c|c|c|c|c|}
\hline \multirow[b]{2}{*}{ Variables } & \multicolumn{5}{|c|}{ OLS Regression on sales growth } & \multicolumn{5}{|c|}{ Ordered Logit on ROI } \\
\hline & (1) & (2) & (3) & (4) & (5) & (6) & (7) & (8) & (9) & (10) \\
\hline Contract-based Internationalization & & $\begin{array}{l}6.88^{* *} \\
(2.04)\end{array}$ & $\begin{array}{l}4.43 \\
(1.10)\end{array}$ & $\begin{array}{c}5.06 \\
(1.35)\end{array}$ & $\begin{array}{l}9.94^{* * *} \\
(2.76)\end{array}$ & & $\begin{array}{l}-0.56^{*} \\
(-1.67)\end{array}$ & $\begin{array}{l}-1.20^{* * *} \\
(-2.95)\end{array}$ & $\begin{array}{l}-0.93^{* *} \\
(-2.49)\end{array}$ & $\begin{array}{l}-0.13 \\
(-0.37)\end{array}$ \\
\hline Asset-based Intln $\times$ Board meeting & & & $\begin{array}{l}6.16^{*} \\
(1.97)\end{array}$ & & & & & $\begin{array}{r}0.54^{*} \\
(1.68)\end{array}$ & & \\
\hline Contract-based Intln $\times$ Board meeting & & & $\begin{array}{l}2.40 \\
(1.05)\end{array}$ & & & & & $\begin{array}{l}0.63^{* * *} \\
(2.84)\end{array}$ & & \\
\hline Asset-based Intln $\times$ ID & & & & $\begin{array}{l}1.91 \\
(0.82)\end{array}$ & & & & & $\begin{array}{c}0.41^{*} \\
(1.73)\end{array}$ & \\
\hline Contract-based Intln $\times$ ID & & & & $\begin{array}{l}2.98 \\
(1.09)\end{array}$ & & & & & $\begin{array}{l}0.61^{* *} \\
(2.16)\end{array}$ & \\
\hline Asset-based Intln $\times$ FD & & & & & $\begin{array}{l}-4.93 \\
(-0.32)\end{array}$ & & & & & $\begin{array}{c}0.55 \\
(0.41)\end{array}$ \\
\hline Contract-based Intln $\times$ FD & & & & & $\begin{array}{l}-18.38^{* *} \\
(-2.32)\end{array}$ & & & & & $\begin{array}{l}-2.53^{* * *} \\
(-3.17)\end{array}$ \\
\hline Log likelihood & & & & & & -289.75 & -287.04 & -282.46 & -284.03 & -280.68 \\
\hline Cragg-Uhler $R^{2}$ & & & & & & 0.16 & 0.18 & 0.22 & 0.21 & 0.23 \\
\hline$R^{2}$ & 0.16 & 0.17 & 0.19 & 0.18 & 0.20 & & & & & \\
\hline
\end{tabular}

Notes: $t$ statistics are in parentheses; $\mathcal{N}=225 ;{ }^{*} p<0.1,{ }^{* *} p<0.05,{ }^{* * *} p<0.01$. 
Models 1 and 6 in Tables 2 and 3 are the baseline models, which only include control variables and the set of industry dummies. Firm size has a positive effect on profitability but no significant effect on firm growth, suggesting that firm size serves as a proxy for firm resources. By contrast, firm age is negatively related to growth but not to profitability. Older firms have more constraints in growing than young firms (Hannan \& Freeman, 1983) but not necessarily lower firm efficiency. Firms in the developmental or maturing stages are stronger in growth than in profitability. Highly leveraged firms have greater growth rates but are not significantly different from firms with low leverage in ROI. Firms with more guanxi have advantages in achieving better profitability, but not necessarily in sales growth. Founder education has a greater effect on enhancing firm profitability than growth, and founder tenure has a positive effect on profitability but no significant effect on firm growth. Finally, founder past overseas experience increases firm sales growth but has no significant effect on ROI.

Models 2 and 7 in Tables 2 and 3 test Hypotheses 1 and 2, which predict that internationalization has a positive effect on firm growth but a negative effect on firm profitability. Consistent with the prediction in Hypothesis 1, the internationalization measure in Model 2 of Table 2 and the contract-based and asset-based internationalization measures in Model 2 of Table 3 all have positive signs, though the positive effect of asset-based internationalization on firm growth was not significant. Thus, Hypothesis 1 received good support. The internationalization measure in Model 7 of Table 2 and the asset-based and contract-based internationalization measures in Model 7 of Table 3 have negative and significant effects on firm ROI, lending strong support to Hypothesis 2.

Hypothesis 3 a predicts that the frequency of board meetings positively moderates the relationship between internationalization and firm performance. As Models 3 and 8 in Table 2 show, the coefficients of the interactions between the frequency of board meetings and internationalization are positive and significant for both growth and ROI. The coefficient of the interaction between assetbased internationalization and the frequency of board meetings is also significant and positive, but the coefficient of the interaction between contract-based internationalization and the frequency of board meetings is not significant in Model 3 of Table 3; however, both interactions are significant and positive in Model 8 of Table 3. Thus, Hypothesis 3a is partially supported. Hypothesis 3b states that the number of independent directors positively moderates the relationship between internationalization and firm performance. Models 4 and 9 of Tables 2 and 3 test this hypothesis. The coefficients of the interactions are all positive and significant in the models with firm ROI as the dependent variable but not in models with growth as the dependent variable. Thus, Hypothesis $3 \mathrm{~b}$ is partially supported. Consistent with Hypothesis 3c, which predicts that family dominance in the TMT negatively moderates the relationship between internationalization and firm performance, Models 5 and 10 of Table 2 present negative and significant coefficients of the interactions between family dominance in the TMT and the internationalization 
dummy. In Models 5 and 10 of Table 3, only the coefficients of the interactions between contract-based internationalization and family dominance in the TMT are negative and significant for both growth and ROI. Taking these together, Hypothesis $3 \mathrm{c}$ is partially supported.

\section{Robustness Check}

We conducted a few robustness checks using alternative measures and alternative modeling procedures. We used 'the number of internationalization modes' as an alternative independent variable. This variable is determined by the number of boxes ticked to the question 'Which activities does your company undertake in the process of overseas economic and trade exchange'? The more checked boxes there were, the more internationalization modes the firm employed. Table 4 shows the results from regressing firm performance on the number of internationalization modes. The results are consistent with those in Tables 2 and 3.

For the OLS model on firm growth, we used robustness standard errors to handle potential heteroskedasticity issues. The results are consistent with or without robustness standard errors. For firm profitability measured as ROI, we used generalized ordered logistic regression, which relaxes the proportional odds assumption. Again, the results remain consistent. In addition, we used OLS regression instead of ordered logistic regression. As Table 5 shows, the results are again consistent with those in Tables 2 and 3.

To verify the moderating effect of family dominance in the TMT, we also conducted a split sample analysis. The results are consistent with the interactions in the regression analyses. The coefficient of internationalization is significant and positive when family dominance in the TMT is absent but is not significant when family dominance is present. The coefficient of internationalization on ROI is negative and significant when the family dominates the TMT but is not significant when the family does not.

\section{DISGUSSION}

The purpose of this study was to examine the relationship between Chinese family firms' outward internationalization activities and firm performance, as well as the moderating role of corporate governance. In a sample of 225 family firms in China, we find that internationalization has a positive impact on growth but a negative impact on profitability. However, this negative effect on profitability can be reduced or reversed as the degree of board activeness and board independence increases and when family members do not dominate the TMT. We illustrate the moderating effects in Figure 2, which we developed from Models 3-5 of Table 5.

The findings contribute to the family business literature by providing one of the first tests on the performance implications of internationalization strategy and by 
Table 4. Robustness check - regression analyses: effect of number of internationalization modes on firm performance

\begin{tabular}{|c|c|c|c|c|c|c|c|c|c|c|}
\hline \multirow[b]{2}{*}{ Variables } & \multicolumn{5}{|c|}{ OLS Regression on sales growth } & \multicolumn{5}{|c|}{ Ordered Logit on ROI } \\
\hline & (1) & (2) & (3) & (4) & (5) & (6) & (7) & (8) & (9) & (10) \\
\hline \multirow[t]{2}{*}{ Firm size } & 1.68 & 0.45 & 0.24 & 0.36 & -0.10 & $0.43^{*}$ & $0.56^{* * *}$ & $0.53^{* *}$ & $0.56^{* * *}$ & $0.49^{* *}$ \\
\hline & $(0.82)$ & $(0.21)$ & $(0.11)$ & $(0.17)$ & $(-0.05)$ & $(2.07)$ & $(2.62)$ & $(2.48)$ & $(2.60)$ & $(2.26)$ \\
\hline \multirow[t]{2}{*}{ Firm age } & $-4.97^{* *}$ & $-5.12^{* *}$ & $-5.40^{* *}$ & $-5.17^{* *}$ & $-5.07^{* *}$ & -0.28 & -0.27 & -0.31 & -0.29 & -0.25 \\
\hline & $(-2.07)$ & $(-2.15)$ & $(-2.28)$ & $(-2.18)$ & $(-2.13)$ & $(-1.22)$ & $(-1.18)$ & $(-1.35)$ & $(-1.24)$ & $(-1.10)$ \\
\hline \multirow[t]{2}{*}{ Firm stage } & $6.61^{* *}$ & $6.98^{* *}$ & $7.07^{* *}$ & $7.09^{* *}$ & $6.97^{* *}$ & 0.39 & 0.39 & 0.41 & 0.39 & 0.38 \\
\hline & $(2.17)$ & $(2.31)$ & $(2.35)$ & $(2.35)$ & $(2.31)$ & $(1.31)$ & $(1.30)$ & $(1.38)$ & $(1.31)$ & $(1.29)$ \\
\hline \multirow[t]{2}{*}{ Inward FDI } & 2.17 & 1.96 & 1.16 & 1.69 & 1.75 & 0.22 & 0.25 & 0.18 & 0.23 & 0.22 \\
\hline & $(0.75)$ & $(0.68)$ & $(0.40)$ & $(0.59)$ & $(0.61)$ & $(0.80)$ & $(0.90)$ & $(0.64)$ & $(0.81)$ & $(0.79)$ \\
\hline \multirow[t]{2}{*}{ Leverage } & $4.50^{*}$ & 4.04 & 4.45 & 4.11 & 4.35 & -0.13 & -0.10 & -0.05 & -0.09 & -0.05 \\
\hline & $(1.76)$ & $(1.45)$ & $(1.60)$ & $(1.48)$ & $(1.55)$ & $(-0.49)$ & $(-0.36)$ & $(-0.19)$ & $(-0.32)$ & $(-0.18)$ \\
\hline \multirow[t]{2}{*}{ Guanxi } & 1.60 & 1.59 & 1.10 & 1.38 & 1.59 & $0.28^{*}$ & $0.28^{* *}$ & 0.23 & $0.27^{*}$ & $0.28^{*}$ \\
\hline & $(1.09)$ & (1.09) & $(0.75)$ & $(0.95)$ & $(1.09)$ & $(1.96)$ & $(1.98)$ & $(1.60)$ & $(1.89)$ & $(1.95)$ \\
\hline \multirow[t]{2}{*}{ Founder education } & $1.95^{*}$ & 1.71 & 1.55 & 1.77 & 1.72 & $0.21^{*}$ & $0.24^{* *}$ & $0.23^{* *}$ & $0.25^{* *}$ & $0.24^{* *}$ \\
\hline & $(1.75)$ & $(1.54)$ & $(1.40)$ & $(1.60)$ & $(1.55)$ & $(1.92)$ & $(2.16)$ & $(2.07)$ & $(2.23)$ & $(2.15)$ \\
\hline \multirow[t]{2}{*}{ Founder tenure } & -0.17 & -0.15 & -0.14 & -0.14 & -0.13 & $0.05^{* *}$ & $0.05^{* *}$ & $0.05^{* *}$ & $0.05^{* *}$ & $0.05^{* *}$ \\
\hline & $(-0.75)$ & $(-0.67)$ & $(-0.62)$ & $(-0.62)$ & $(-0.58)$ & $(2.16)$ & $(2.06)$ & $(2.20)$ & $(2.16)$ & $(2.13)$ \\
\hline \multirow[t]{2}{*}{ Founder overseas experience } & $23.21^{*}$ & $21.59^{*}$ & $22.07^{*}$ & $20.71^{*}$ & $21.11^{*}$ & 0.13 & 0.27 & 0.29 & 0.17 & 0.19 \\
\hline & $(1.95)$ & $(1.82)$ & (1.88) & $(1.75)$ & $(1.79)$ & $(0.12)$ & $(0.26)$ & $(0.28)$ & $(0.16)$ & $(0.19)$ \\
\hline \multirow[t]{2}{*}{ Board meeting } & 0.01 & 0.29 & -0.86 & 0.13 & 0.07 & 0.08 & 0.06 & -0.07 & 0.04 & 0.02 \\
\hline & $(0.01)$ & $(0.26)$ & $(-0.67)$ & $(0.12)$ & $(0.06)$ & $(0.76)$ & $(0.50)$ & $(-0.59)$ & $(0.40)$ & $(0.21)$ \\
\hline \multirow[t]{2}{*}{ Independent director (ID) } & 0.91 & 0.78 & 0.48 & -0.35 & 0.85 & 0.12 & 0.14 & 0.10 & 0.03 & 0.15 \\
\hline & $(0.77)$ & $(0.67)$ & $(0.40)$ & $(-0.25)$ & $(0.73)$ & $(1.06)$ & $(1.20)$ & $(0.86)$ & $(0.21)$ & $(1.30)$ \\
\hline \multirow[t]{2}{*}{ Family dominance in the TMT (FD) } & 3.33 & 2.99 & 4.14 & 3.48 & 8.48 & -0.16 & -0.11 & 0.01 & -.07 & 0.66 \\
\hline & $(0.90)$ & $(0.83)$ & $(1.15)$ & $(0.97)$ & $(1.59)$ & $(-0.46)$ & $(-0.32)$ & $(0.02)$ & $(-0.22)$ & $(1.23)$ \\
\hline Industry dummy & Included & Included & Included & Included & Included & Included & Included & Included & Included & Included \\
\hline \multirow{2}{*}{ Number of internationalization modes } & & $3.41^{*}$ & 1.19 & 2.19 & $4.36^{* *}$ & & $-0.36^{* *}$ & $-0.61^{* * *}$ & $-0.46^{* *}$ & -0.23 \\
\hline & & $(1.95)$ & $(0.58)$ & $(1.16)$ & $(2.33)$ & & $(-2.03)$ & $(-2.84)$ & $(-2.41)$ & $(-1.20)$ \\
\hline
\end{tabular}


Table 4. Countinued

\begin{tabular}{|c|c|c|c|c|c|c|c|c|c|c|}
\hline \multirow[b]{2}{*}{ Variables } & \multicolumn{5}{|c|}{ OLS Regression on sales growth } & \multicolumn{5}{|c|}{ Ordered Logit on ROI } \\
\hline & (1) & (2) & (3) & (4) & (5) & (6) & (7) & (8) & (9) & $(10)$ \\
\hline Intln modes $\times$ Board meeting & & & $\begin{array}{l}2.54^{* *} \\
(1.98)\end{array}$ & & & & & $\begin{array}{l}0.28^{* *} \\
(2.14)\end{array}$ & & \\
\hline Intln modes $\times$ ID & & & & $\begin{array}{r}2.00^{*} \\
(1.74)\end{array}$ & & & & & $\begin{array}{c}0.18 \\
(1.40)\end{array}$ & \\
\hline Intln modes $\times$ FD & & & & & $\begin{array}{l}-6.60 \\
(-1.39)\end{array}$ & & & & & $\begin{array}{l}-0.91^{*} \\
(-1.84)\end{array}$ \\
\hline Log likelihood & & & & & & -289.75 & -287.65 & -285.34 & -286.62 & -285.88 \\
\hline Cragg-Uhler $R^{2}$ & & & & & & 0.16 & 0.18 & 0.20 & 0.19 & 0.19 \\
\hline$R^{2}$ & 0.16 & 0.17 & 0.19 & 0.18 & 0.18 & & & & & \\
\hline
\end{tabular}

Notes: $t$ statistics are in parentheses; $\mathcal{N}=225 ;{ }^{*} p<0.1,{ }^{* *} p<0.05,{ }^{* * *} p<0.01$ 
Table 5. OLS regression analyses: effect of outward internationalization and asset-based \& contract-based outward internationalization on ROI

\begin{tabular}{|c|c|c|c|c|c|c|c|c|c|}
\hline \multirow[b]{2}{*}{ Variables } & \multicolumn{9}{|c|}{ OLS Regression on ROI } \\
\hline & (1) & (2) & (3) & (4) & (5) & (6) & (7) & $(8)$ & (9) \\
\hline \multirow[t]{2}{*}{ Firm size } & $0.20^{* *}$ & $0.27^{* *}$ & $0.26^{* *}$ & $0.26^{* *}$ & $0.22^{* *}$ & $0.29^{* * *}$ & $0.27^{* *}$ & $0.28^{* *}$ & $0.24^{* *}$ \\
\hline & $(2.03)$ & $(2.60)$ & $(2.49)$ & $(2.54)$ & $(2.11)$ & $(2.70)$ & $(2.56)$ & $(2.67)$ & $(2.27)$ \\
\hline \multirow[t]{2}{*}{ Firm age } & -0.15 & -0.14 & -0.15 & -0.13 & -0.10 & -0.16 & -0.16 & -0.15 & -0.09 \\
\hline & $(-1.30)$ & $(-1.22)$ & $(-1.30)$ & $(-1.14)$ & $(-0.85)$ & $(-1.33)$ & $(-1.39)$ & $(-1.30)$ & $(-0.78)$ \\
\hline \multirow[t]{2}{*}{ Firm stage } & 0.24 & 0.22 & 0.21 & 0.21 & 0.19 & 0.22 & 0.21 & 0.21 & 0.15 \\
\hline & $(1.61)$ & $(1.49)$ & $(1.43)$ & $(1.43)$ & $(1.28)$ & $(1.47)$ & $(1.41)$ & $(1.40)$ & $(1.03)$ \\
\hline \multirow[t]{2}{*}{ Inward FDI } & 0.08 & 0.10 & 0.06 & 0.08 & 0.09 & 0.10 & 0.06 & 0.08 & 0.10 \\
\hline & $(0.58)$ & $(0.68)$ & $(0.41)$ & $(0.60)$ & $(0.66)$ & (0.68) & $(0.42)$ & $(0.58)$ & $(0.73)$ \\
\hline \multirow[t]{2}{*}{ Leverage } & -0.07 & -0.06 & -0.04 & -0.05 & -0.03 & -0.06 & -0.04 & -0.05 & 0.01 \\
\hline & $(-0.54)$ & $(-0.46)$ & $(-0.28)$ & $(-0.38)$ & $(-0.19)$ & $(-0.45)$ & $(-0.27)$ & $(-0.35)$ & $(0.04)$ \\
\hline \multirow[t]{2}{*}{ Guanxi } & $0.15^{* *}$ & $0.16^{* *}$ & $0.13^{* *}$ & $0.15^{* *}$ & $0.17^{* *}$ & $0.17^{* *}$ & $0.13^{*}$ & $0.16^{* *}$ & $0.19^{* * *}$ \\
\hline & $(2.15)$ & $(2.23)$ & $(1.80)$ & $(2.13)$ & $(2.42)$ & $(2.31)$ & $(1.87)$ & $(2.23)$ & $(2.65)$ \\
\hline \multirow[t]{2}{*}{ Founder education } & $0.10^{*}$ & $0.11^{* *}$ & $0.11^{* *}$ & $0.12^{* *}$ & $0.11^{* *}$ & $0.12^{* *}$ & $0.11^{* *}$ & $0.13^{* *}$ & $0.11^{* *}$ \\
\hline & $(1.82)$ & $(2.07)$ & $(1.97)$ & $(2.25)$ & $(2.09)$ & $(2.13)$ & $(2.02)$ & $(2.34)$ & $(2.10)$ \\
\hline \multirow[t]{2}{*}{ Founder tenure } & $0.02^{* *}$ & $0.02^{* *}$ & $0.02^{* *}$ & $0.02^{* *}$ & $0.02^{* *}$ & $0.02^{* *}$ & $0.02^{* *}$ & $0.02^{* *}$ & $0.02^{*}$ \\
\hline & $(2.06)$ & $(2.03)$ & $(2.08)$ & $(1.99)$ & $(2.05)$ & $(2.08)$ & $(2.11)$ & $(2.05)$ & $(1.97)$ \\
\hline \multirow[t]{2}{*}{ Founder overseas experience } & 0.07 & 0.15 & 0.13 & 0.03 & 0.13 & 0.16 & 0.15 & 0.06 & 0.17 \\
\hline & $(0.12)$ & $(0.25)$ & $(0.23)$ & $(0.05)$ & $(0.22)$ & $(0.28)$ & $(0.26)$ & $(0.11)$ & $(0.29)$ \\
\hline \multirow[t]{2}{*}{ Board meeting } & 0.04 & 0.02 & -0.08 & 0.01 & -0.00 & 0.02 & -0.08 & 0.00 & -0.01 \\
\hline & $(0.71)$ & $(0.33)$ & $(-1.17)$ & $(0.17)$ & $(-0.03)$ & $(0.28)$ & $(-1.18)$ & $(0.08)$ & $(-0.14)$ \\
\hline \multirow[t]{2}{*}{ Independent director (ID) } & 0.05 & 0.07 & 0.05 & -0.01 & 0.07 & 0.07 & 0.06 & -0.00 & 0.08 \\
\hline & 0.94 & 1.16 & 0.96 & -0.07 & 1.28 & 1.24 & 1.03 & -0.06 & 1.47 \\
\hline \multirow[t]{2}{*}{ Family dominance in the TMT (FD) } & -0.05 & -0.01 & 0.08 & 0.03 & $0.56^{*}$ & -0.04 & 0.05 & 0.00 & $0.58^{*}$ \\
\hline & $(-0.26)$ & $(-0.06)$ & $(0.43)$ & $(0.16)$ & $(1.87)$ & $(-0.21)$ & $(0.30)$ & $(0.03)$ & $(1.94)$ \\
\hline Industry dummy & Included & Included & Included & Included & Included & Included & Included & Included & Included \\
\hline Internationalization & & $\begin{array}{l}-0.33^{* *} \\
(-2.18)\end{array}$ & $\begin{array}{l}-0.58^{* * *} \\
(-3.34)\end{array}$ & $\begin{array}{l}-0.46^{* * *} \\
(-2.79)\end{array}$ & $\begin{array}{l}-0.20 \\
(-1.28)\end{array}$ & & & & \\
\hline
\end{tabular}


Table 5. Continued

\begin{tabular}{|c|c|c|c|c|c|c|c|c|c|}
\hline \multirow[b]{2}{*}{ Variables } & \multicolumn{9}{|c|}{ OLS Regression on ROI } \\
\hline & (1) & (2) & (3) & (4) & (5) & (6) & (7) & (8) & (9) \\
\hline Intln $\times$ Board meeting & & & $\begin{array}{l}0.27^{* * *} \\
(2.73)\end{array}$ & & & & & & \\
\hline Intln $\times$ ID & & & & $\begin{array}{r}0.18^{*} \\
(1.87)\end{array}$ & & & & & \\
\hline Intln $\times$ FD & & & & & $\begin{array}{l}-0.88^{* *} \\
(-2.34)\end{array}$ & & & & \\
\hline Asset-based Intln & & & & & & $\begin{array}{l}-0.45^{* *} \\
(-2.16)\end{array}$ & $\begin{array}{l}-0.67^{* * *} \\
(-2.73)\end{array}$ & $\begin{array}{l}-0.60^{* *} \\
(-2.58)\end{array}$ & $\begin{array}{l}-0.43^{* *} \\
(-2.05)\end{array}$ \\
\hline Contract-based Intln & & & & & & $\begin{array}{l}-0.26 \\
(-1.59)\end{array}$ & $\begin{array}{l}-0.53^{* * *} \\
(-2.72)\end{array}$ & $\begin{array}{l}-0.40^{* *} \\
(-2.21)\end{array}$ & $\begin{array}{l}-0.08 \\
(-0.46)\end{array}$ \\
\hline Asset-based Intln × Board meeting & & & & & & & $\begin{array}{l}0.25^{*} \\
(176)\end{array}$ & & \\
\hline Contract-based Intln $\times$ Board meeting & & & & & & & $\begin{array}{l}0.27^{* *} \\
(2.45)\end{array}$ & & \\
\hline Asset-based Intln × ID & & & & & & & & $\begin{array}{c}0.18^{*} \\
(1.69)\end{array}$ & \\
\hline Contract-based Intln $\times$ ID & & & & & & & & $\begin{array}{c}0.22^{*} \\
(1.67)\end{array}$ & \\
\hline Asset-based Intln $\times$ FD & & & & & & & & & $\begin{array}{c}0.31 \\
(0.41)\end{array}$ \\
\hline Contract-based Intln $\times$ FD & & & & & & & & & $\begin{array}{l}-1.09^{* * *} \\
(-2.83)\end{array}$ \\
\hline$R^{2}$ & 0.16 & 0.18 & 0.21 & 0.20 & 0.20 & 0.18 & 0.21 & 0.20 & 0.22 \\
\hline
\end{tabular}



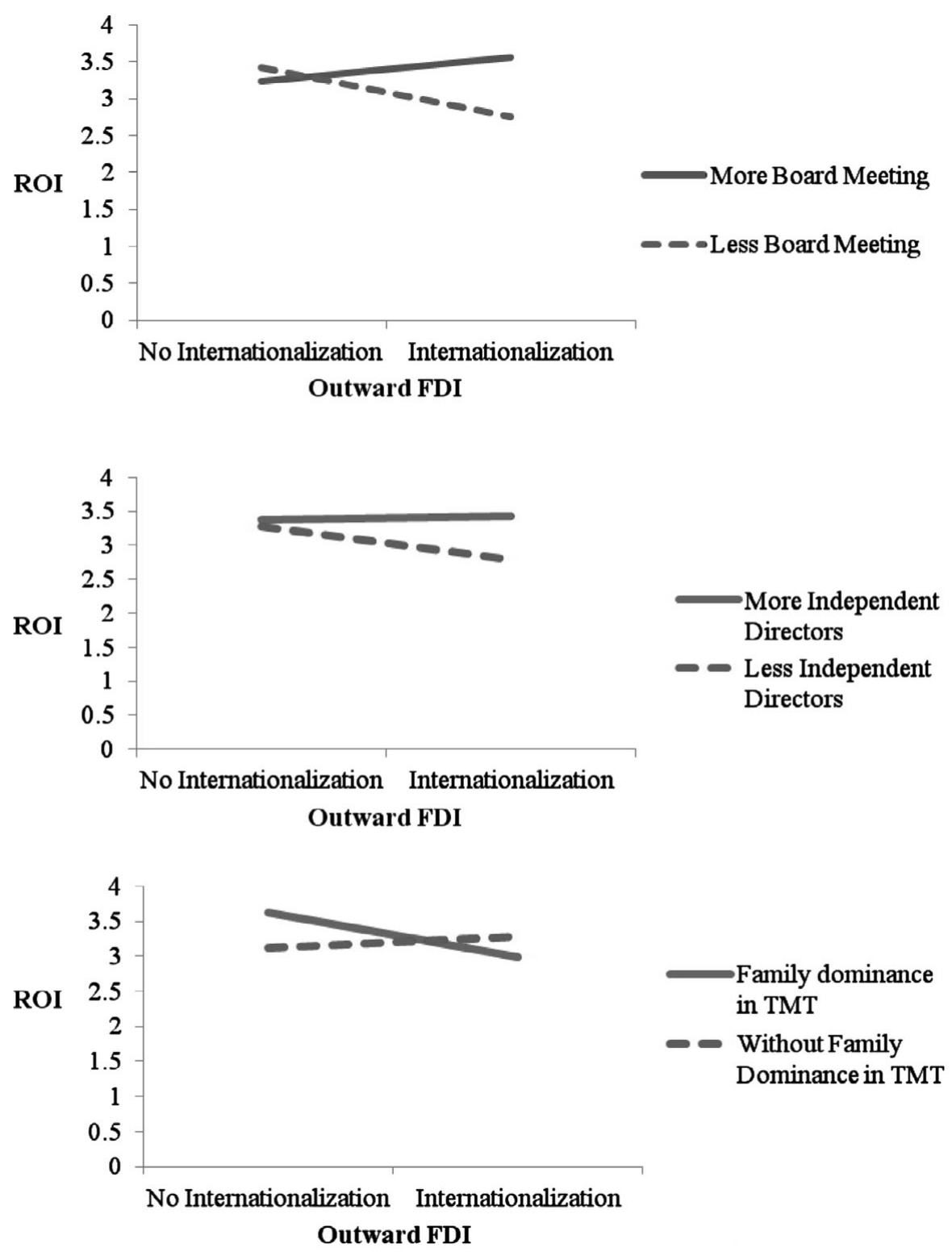

Figure 2. Moderating effect of frequency of board meetings, the number of independent directors, and family dominance in the TMT on internationalization and ROI. (a) Interaction effect of frequency of board meetings, outward FDI, and ROI. (b) Interaction effect of the number of independent directors, outward FDI, and ROI. (c) Interaction effect of family dominance in the TMT, outward FDI, and ROI.

revealing the advantages and disadvantages in the process of internationalization. Our results shed new light on the internationalization-performance relationship by highlighting different motivations and goals associated with an internationalization strategy and by identifying an important moderator - namely, corporate governance - on this relationship. 


\section{Theoretical Implications}

Our study primarily contributes to two streams of literature. With regard to the family business literature, our work is one of the few studies to examine the performance implications of the internationalization of family firms from emerging economies. Such a test reveals the advantages and disadvantages for family firms from emerging economies. The negative impact of internationalization on firm profitability indicates that these firms do not have ownership advantages, as required in the internationalization process (Dunning, 1988), and that there is additional cost to internationalization (i.e., liability of origin) for firms from emerging markets (Holburn \& Zelner, 2010). Our theorization of four liabilities also extends the existing theory on the internationalization of small and medium-sized firms (Lu \& Beamish, 2001), which was based on firms from developed economies and excluded liability of origin, a unique cost for firms from emerging economies. Thus, our theorization illustrates the importance of considering the unique advantages and disadvantages associated with specific types of firms.

With regard to the internationalization-performance literature, we provide new insights by highlighting the multidimensionality of performance and by identifying a new moderator: corporate governance. The differential effect of internationalization on firm growth and profitability found in this study highlights a long neglected point that firm performance is a multidimensional construct and that the same strategy could well have differential effects on different dimensions of firm performance. The investigation of the effect of a particular strategy on different dimensions of performance not only provides a more complete picture of the overall effect but also reveals different motivations and goals associated with the strategy.

Research has found a variety of relationships between internationalization and firm performance (for a review, see $\mathrm{Lu} \&$ Beamish, 2004). The identification of corporate governance as a moderator of the relationship between internationalization and firm performance helps resolve the mixed findings in this literature by illustrating that the main effect depends on particular conditions. Given the significant moderating effect of the contingency factors, the main effect can change from negative to positive or vice versa (see Figure 2). This provides an explanation of the mixed findings in the literature and answers the call for identifying boundary conditions of the relationship rather than continuing examination of the main effect between internationalization and firm performance ( $\mathrm{Lu} \&$ Beamish, 2004).

\section{Managerial Implications}

This research has important practical implications for family firms from emerging economies that are contemplating internationalization. Given the increasing importance of these firms in international markets, there is a need to understand 
the performance effects of an internationalization strategy to guide their further internationalization. This study fills that gap.

More important, our findings that internationalization has a positive impact on firm growth and a negative impact on firm profitability indicate that an internationalization strategy per se does not lead to success. Internationalization may help family firms from emerging economies achieve growth but at heightened costs, as illustrated by the decline in firm profitability as family firms in our study internationalized. Value might be associated with internationalization strategy but such value can only be realized when there is appropriate implementation of this strategy. Specifically, our study highlights the importance of good corporate governance, such as increases in board activeness, board independence, and the appointment of nonfamily members to the TMT. Only when these corporate governance practices are in place can family firms from emerging economies benefit from their own internationalization.

\section{Limitations and Future Research}

The implications from this study should be interpreted in light of its limitations. Our analyses to test Hypotheses 1 and 2 may suffer from several measurement and testing issues raised by Verbeke and Forootan (2012). First, our independent variables do not capture the diversity in country profiles or the relationship of the host country to the home country. Because the concept of distance is critical for exploiting firmspecific advantages across countries, it would be helpful to have information on country destination to construct a distance-weighted internationalization measure or add a distance measure as a control or moderator to the model.

Second, we advanced the internationalization and performance literature by examining two dimensions of performance: growth and profitability. However, these are overall performance indicators at the firm level. It would be ideal to isolate the performance driven solely by foreign operations from the overall performance. Future research should use foreign performance as an alternative dependent variable or compare the internationalizing and comparable domestic firms (Lu \& Beamish, 2001) to understand the real effect of internationalization.

Third, the snapshot nature of survey data provides insufficient information for us to test reverse causality and endogeneity issues or to consider the dynamic aspect of the relationship between internationalization and performance. We cannot rule out the possibility that better-performing firms or resource-abundant firms set higher internationalization goals. Although we include several control variables, the crosssectional nature of our data remains a study limitation.

Fourth, other important contingencies can affect the relationship between internationalization and performance. FDI motives and industry structures determine the internationalization strategies and, thus, the outcome. In addition, research has shown that the order of entry affects market share resulting from foreign operations (Delios \& Makino, 2003). Product diversification can interact 
with international diversification and affect its outcome (Hitt et al., 1997). Unfortunately, such information is unavailable to us. Future studies should take into consideration these contingency factors to gain a more complete understanding of the internationalization-performance relationship.

In addition to the general issues related to the internationalization-performance relationship, our results reflect the performance impact of internationalization expansion for Chinese family firms. Although our findings are likely generalizable to family firms in other economies, institutional differences should be taken into consideration. It would be useful for future studies to examine family firms in other contexts to verify and extend the generalizability of our findings.

Likewise, it would be worthwhile to examine the moderating role of organization structure in the internationalization-performance relationship in other types of firms. We focused on family firms because the lack of stringent corporate governance is a pronounced feature of such firms. However, a contingency perspective likely applies to all firms. Different types of firms will have different dimensions of organizational structure. Thus, future research should continue to explore this line of research and identify relevant dimensions of organizational structure in different types of firms in the process of internationalization.

In this study, we tried to minimize common method bias through presurvey and postsurvey procedures; however, such a bias cannot be completely eliminated because all the information for this study is from the same source. Whenever possible, future studies should collect information from different sources in research design to remove such bias.

The choice of 'above 80\%' as a cutoff point to represent dominance in the TMT may seem arbitrary. We explored different ranges of ratios of family members in the TMT and found that the results are sensitive to the change in cutoff points. This sensitivity may indicate nonlinear performance implications of the influence of family dominance in family firms, a notion which future studies could explore. Another shortcoming related to the TMT is the lack of full information on TMT diversity, as the family versus nonfamily member distinction in TMT composition only measures one dimension of TMT diversity. Other dimensions of TMT diversity (e.g., gender, functional background) could provide a more complete picture of TMT diversity and are worthy directions for future research.

The $R$-square of our results is lower than desired. It would be ideal to have information on previous-year performance, which would significantly boost the explanatory power of the models. It would be useful to collect such information in studies that involve firm performance.

Despite these limitations, this study provides one of the first tests of the relationship between internationalization and performance in family firms from China. Our theoretical model incorporates the unique features of Chinese family firms and extends existing theory on the internationalization-performance relationship. Our empirical findings underscore the risk of internationalization strategy and the value of good corporate governance as family firms expand 
into international markets. Our findings demonstrate the importance for better fit between strategy and structure.

\section{GONGLUSION}

In developing a contingency model of the relationship between internationalization and performance, this study highlights the need to consider how organization structure, such as a firm's corporate governance, influences the performance outcomes of an internationalization strategy. While the differential effects of internationalization on different dimensions of performance highlight the importance of considering different motives and outcomes associated with a particular strategy, the negative impact of internationalization on profitability demonstrates the daunting challenges of geographic expansion, especially for family firms from emerging markets.

\section{SUPPLEMENTARY MATERIAL}

To view supplementary material for this article, please visit http://dx.doi.org/ $10.1017 /$ mor.2015.32

\section{REFERENGES}

Aronoff, C. E., \& Ward, J. L. 2000. More than family: Non-family executives in the family business. Marietta, GA: Family Enterprise Publishers.

Bartlett, G. A., \& Ghoshal, S. 1989. Managing across borders: The transnational solution. Boston: Harvard Business School Press.

Bartlett, C. A., \& Ghoshal, S. 2000. Going global: Lessons from late movers. Harvard Business Review, 78(2): 132-142.

Brewer, M. B. 1981. Ethnocentrism and its role in intergroup trust. In M. Brewer \& B. Collins (Eds.), Scientific inquiry in the social sciences: 214-231. San Francisco: Jossey-Bass.

Buckley, P. J., \& Casson, M. 1976. The future of the multinational enterprise (Vol. 1). London: Macmillan.

Cannella, A. A., Park, J. H., \& Lee, H. U. 2008. Top management team functional background diversity and firm performance: Examining the roles of team member colocation and environmental uncertainty. Academy of Management Journal, 51(4): 768-784.

Casillas, J. C., \& Acedo, F. J. 2005. Internationalization of Spanish family SMEs: An analysis of family involvement. International Journal of Globalization and Small Business, 1(2): 134-151.

Casson, M. 1982. The entrepreneur: An economic theory. Totowa, NJ: Barnes \& Nobel Books.

Caves, R. E. 1980. Industrial organization, corporate strategy and structure. Journal of Economic Literature, 18(1): 64-92.

Chang, S. J. 2003. Ownership structure, expropriation, and performance of group-affiliated companies in Korea. Academy of Management Journal, 46(2): 238-253.

Chang, S. J., van Witteloostuijn, A., \& Eden, L. 2010. From the editors: Common method variance in international business research.Journal of International Business Studies, 41(2): 178-184.

Chen, E. T., \& Nowland, J. 2010. Optimal board monitoring in family-owned companies: Evidence from Asia. Corporate Governance: An International Revieze, 18(1): 3-17.

Chua, J. H., Chrisman, J. J., \& Bergiel, E. B. 2009. An agency theoretic analysis of the professionalized family firm. Entrepreneurship: Theory and Practice, 33(2): 355-372.

Chua, J. H., Chrisman, J.J., \& Sharma, P. 1999. Defining the family business by behavior. Entrepreneurship: Theory and Practice, 23(4): 19-40. 
Claver, E., Rienda, L., \& Quer, D. 2009. Family firms' international commitment: The influence of family-related factors. Family Business Review, 22(2): 125-135.

Contractor, F. J., Kundu, S. K., \& Hsu, C. 2003. A three-stage theory of international expansion: The link between multinationality and performance in the service sector.Journal of International Business Studies, 34(1): 5-18.

Corbetta, G., \& Salvato, C. A. 2004. The board of directors in family firms: One size fits all? Family Business Revieze, 17(2): 119-134.

Davis, P. S., \& Harveston, P. D. 1999. In the founder's shadow: Conflict in the family firm. Family Business Revieze, 12(4): 311-323.

Delios, A., \& Beamish, P. W. 2001. Survival and profitability: The influence of intangible assets and experience on subsidiary performance. Academy of Management Journal, 44(6): 10281038.

Delios, A., \& Makino, S. 2003. Timing of entry and the foreign subsidiary performance of Japanese firms. Journal of International Marketing, 11(3): 83-105.

Denis, D. J., Denis, D. K., \& Yost, K. 2002. Global diversification, industrial diversification, and firm value. Journal of Finance, 57(5): 1951-1979.

Dunning, J. H. 1988. The eclectic paradigm of international production: A restatement and some possible extensions. Journal of International Business Studies, 19(1): 1-31.

Dunning, J. H. 1993. Multinational enterprises and the global economy. Boston: AddisonWesley Publishing Company.

Dyer, W. G. 1989. Integrating professional management into a family owned business. Family Business Revieze, 2(3): 221-235.

Erdener, C., \& Shapiro, D. M. 2005. The internationalization of Chinese family enterprises and Dunning's eclectic MNE paradigm. Management and Organization Revieze, 1(3): 411 436.

Fama, E. F., \& Jensen, M. C. 1983. Separation of ownership and control. Journal of Lawe and Economics, 26(2): 301-325.

Fernández, Z., \& Nieto, M. J. 2005. Internationalization strategy of small and medium-sized family businesses: Some influential factors. Family Business Revieze, 18(1): 77-89.

Gallo, M. A., \& Pont, C. G. 1996. Important factors in family business internationalization. Family Business Revieze, 9(1), 45-59.

Gallo, M. A., \& Sveen, J. 1991. Internationalizing the family business: Facilitating and restraining factors. Family Business Revieze, 4(2): 181-190.

Geringer, J. M., Tallman, S., \& Olsen, D. M. 2000. Product and international diversification among Japanese multinational firms. Strategic Management Journal, 21(1): 51-80.

Hambrick, D. C., Cho, T. S., \& Chen, M.J. 1996. The influence of top management team heterogeneity on firms' competitive moves. Administrative Science Quarterly, 41(4): 659 684.

Hannan, M. T., \& Freeman, J. 1983. The liability of newness: Age dependence in organizational death rates. American Sociological Revieze, 48(5): 692-710.

Hitt, M., Hoskisson, R., \& Kim, H. 1997. International diversification: Effects on innovation and firm performance in product diversified firms. Academy of Management Journal, 40(4): 767-798.

Holburn, G., \& Zelner, B. A. 2010. Political capabilities, policy risk, and international investment strategy: Evidence from the global electric power generation industry. Strategic Management Journal, 31(12): 1290-1315.

Hu, L. T., \& Bentler, P. M. 1999. Cutoff criteria for fit indexes in covariance structure analysis: Conventional criteria versus new alternatives. Structural Equation Modeling: $\boldsymbol{A}$ Multidisciplinary Journal, 6(1): 1-55.

Hymer, S. H. 1960. The international operations of national firms: A study of direct foreign investment. Doctoral dissertation, MIT.

James Jr., H.S., 1999. Owners as manager, extended horizons and the family firm. International Journal of the Economics of Business, 6(1): 41-55.

Jensen, M. C. 1994. Self-interest, altruism, incentives, and agency theory. Journal of Applied Corporate Finance, 7(2): 40-45.

Johanson,J., \& Vahlne, J. E. 1977. The internationalization process of the firm: A model of knowledge development and increasing foreign market commitments. Journal of International Business Studies, 8(1): 23-32.

Johnson, J. L., Daily, C. M., \& Ellstrand, A. E. 1996. Boards of directors: A review and research agenda.Journal of Management, 22(3): 409-438.

(C) 2015 The International Association for Chinese Management Research 
Kets de Vries, M. F. R. 1993. The dynamics of family controlled firms. Organizational Dynamics, $21(3), 59-71$.

Kogut, B. 1985. Designing global strategies: Profiting from operational flexibility. Sloan Management Review, 27(1): 27-38.

Kutner, M. H., Nachtsheim, G.J., \& Neter, J. 2004. Applied linear regression models, 4th edition. Chicago: McGraw-Hill/Irwin.

La Porta, R., López, de Silanes, F., \& Shleifer, A. 1999. Corporate ownership around the world. Journal of Finance, 54(2): 47 1-517.

Lawrence, P. R., \& Lorsch, J. W. 1967. Differentiation and integration in complex organizations. Administrative Science Quarterly, 12(1): 1-47.

Leach, P. 2007. Family businesses: The essentials. London: Profile Books.

Liang, X., Lu, X., \& Wang, L. 2012. Outward internationalization of private enterprises in China: The effect of competitive advantages and disadvantages compared to home market rivals. Journal of World Business, 47(1): 134-144.

Liu, X., Xiao, W., \& Huang, X. 2008. Bounded entrepreneurship and internationalization of indigenous Chinese private-owned firms. International Business Revieze, 17(4): $488-508$.

Lu, J. W., \& Beamish, P. W. 2001. The internationalization and performance of SMEs. Strategic Management Journal, 22(6-7): 565-586.

Lu, J. W., \& Beamish, P. W. 2004. Internationalization diversification and firm performance: The S-curve hypothesis. Academy of Management Journal, 47(4): 598-609.

Luo, Y. 1997. Guanxi: Principles, philosophies, and implications. Human Systems Management, 16(1): 43-51.

Luo, Y. D. 2006. Opportunism in inter-firm exchanges in emerging markets. Management and Organization Revieze, 2(1): 121-147.

Luo, Y., \& Tung, R. L. 2007. International expansion of emerging market enterprises: A springboard perspective. Journal of International Business Studies, 38(4): 481-498.

McDougall, P. P., \& Oviatt, B. M. 1996. New venture internationalization, strategic change, and performance: A follow-up study.Journal of Business Venturing, 11(1): 23-40.

Melin, L., \& Nordqvist, M. 2007. The reflexive dynamics of institutionalization: The case of the family business. Strategic Organization, 5(3): 321-333.

Morck, R., \& Yeung, B. 1991. Why investors value multinationality. Journal of Business, 64(2): 165-187.

Naughton, B. 2007. The Chinese economy: Transitions and growth. Cambridge, MA: The MIT Press.

Okoroafo, S. C. 1999. Internationalization of family businesses: Evidence from Northwest Ohio, USA. Family Business Revieze, 12(2): 147-158.

Oviatt, B. M., \& McDougall, P. P. 2005. Defining international entrepreneurship and modeling the speed of internationalization. Entrepreneurship: Theory and Practice, 29(5): 537-554.

Peng, M. W. 2004. Outside directors and firm performance during institutional transitions. Strategic Management Journal, 25(5): 453-471.

Peng, M. W., Zhang, S., \& Li, X. 2007. CEO duality and firm performance during China's institutional transitions. Management and Organization Revieze, 3(2): 205-225.

Perrow, C. 1967. A framework for the comparative analysis of organizations. American Sociological Revieze, 32(2): 194-208.

Pfeffer, J. 1972. Size and composition of corporate boards of directors: The organization and its environment. Administrative Science Quarterly, 17(2): 218-228.

Podsakoff, P. M., MacKenzie, S. B., Lee, J.-Y., \& Podsakoff, N. P. 2003. Common method biases in behavioral research: A critical review of the literature and recommended remedies.Journal of Applied Psychology, 88(5): 879-903.

Poncet, S. 2003. Measuring Chinese domestic and international integration. China Economic Revieze, 14(1): 1-21.

Porter, M. E. 1986. Competition in global industries: A conceptual framezork. Boston: Harvard Business School Press.

Ramachandran, J., \& Pant, A. 2010. The liabilities of origin: An emerging economy perspective on the costs of doing business abroad. Advances in International Management, 23: 231-265.

Schott, P. K. 2004. Across-product versus within-product specialization in international trade. Quarterly Journal of Economics, 119(2): 647-678.

Sciascia, S., \& Mazzola, P. 2008. Family involvement in ownership and management: Exploring nonlinear effects on performance. Family Business Revieze, 21(4): 331-345.

(C) 2015 The International Association for Chinese Management Research 
Sharma, P., Chrisman, J. J., \& Chua, J. H. 1997. Strategic management of the family business: Past research and future challenges. Family Business Review, 10(1): 1-35.

Stinchcombe, A. L. 1965. Social structure and organizations. In J. G. March (Ed.), Handbook of organizations: $142-193$. Chicago: Rand-McNally.

Teece, D. J. 1980. Economics of scope and the scope of the enterprises. Journal of Economic Behavior and Organization, 1(3): 223-247.

Vafeas, N. 1999. Board meeting frequency and firm performance. Journal of Financial Economics, 53(1): 113-142.

Verbeke, A., \& Forootan, M. Z. 2012. How good are multinationality-performance (M-P) empirical studies? Global Strategy Journal, 2(4): 332-344.

Wan, W. P., \& Hoskisson, R. E. 2003. Home country environments, corporate diversification strategies, and firm performance. Academy of Management Journal, 46(1): 27-45.

Young, A. 2000. The razor's edge: Distortions and incremental reform in the People's Republic of China. Quarterly Journal of Economics, 115(4): 1091-1135.

Zaheer, S. 1995. Overcoming the liability of foreignness. Academy of Management Journal, 38(2): 341-363.

Zahra, S. A. 2003. International expansion of U.S. manufacturing family businesses: The effect of ownership and involvement. Journal of Business Venturing, 18(4): 495-512.

Zahra, S. A., \& Garvis, D. M. 2000. International corporate entrepreneurship and firm performance: The moderating effect of international environmental hostility. Journal of Business Venturing, 15(5): 469-492.

Zahra, S. A., \& Pearce, J. A. 1989. Boards of directors and corporate financial performance: A review and integrative model. Journal of Management, 15(2): 291-334. 
Jane Wenzhen Lu (jane.lu@unimelb.edu.au) is Professor of Management and the James Riady Chair in Asian Business and Economics at the Faculty of Business and Economics, the University of Melbourne. She received her $\mathrm{PhD}$ from the Richard Ivey School of Business, University of Western Ontario. Her research centers on international strategy such as FDI location choice, entry mode choice, and alliance partner selection. Her recent research continues this line of research but with a focus on emerging market firms and their internationalization.

Xueji Liang (xuejiliang@u.nus.edu) is Assistant Professor at the Business School, Sun Yat-sen University. She received her $\mathrm{PhD}$ from the National University of Singapore. Her research includes issues related to internationalization and corporate social responsibility.

Mengmeng Shan (mmshan@shu.edu.cn) is Assistant Professor at the School of Management, Shanghai University. She received her PhD from the School of Management, Fudan University. Her research interests lie in international strategy, the determinants and effects of foreign direct investment, and multinational enterprises in emerging economies.

Xiaoya Liang (xyliang@fudan.edu.cn) is Associate Professor at the School of Management, Fudan University. She received her PhD from the State University of New York at Albany. Her primary research interests include Chinese private firms, e-HR, and strategic compensation.

Manuscript received: March 11, 2013

Final version accepted: July 3, 2015

Accepted by:

Brad Kirkman 